\title{
THE SUPREME COURT ENTRENCHES PARLIAMENTARY PRIVILEGE OUT OF THE CHARTER'S REACH: DONAHOE v. CBC
}

\author{
Andrew Heard
}

The Supreme Court of Canada recently delivered its judgment in Donahoe $v C B C,{ }^{1}$ a case from which repercussions will be felt for some time to come. While its immediate effects are limited, the reasons given by the court ultimately will be applied in a wide range of cases dealing with both the Charter of Rights and the federal division of powers.

\section{INTRODUCTION}

Donahoe primarily resolves a dispute between the Nova Scotia House of Assembly and the Press Gallery over the right of TV journalists to cover the proceedings in the legislature, using their own hand-held cameras from the balcony press box. The Supreme Court of Canada rejected, 7-1, the media claims that the Charter of Rights entitled them to such access to the chamber.

Regardless of the outcome of this case, its immediate effects on the litigants were going to be limited. Although there was no television coverage of the House of Assembly when a local TV station first initiated the suit, the legislature had responded to losses in the trial and appellate courts with the introduction of its own closed circuit coverage of debates. The Assembly installed a system of remote-controlled cameras that focused on the MLA who had the floor, as has been the practise in the House of Commons for over a decade, and provided a live feed to the media. Pending the appeal to the Supreme Court, hand-held TV cameras were allowed in the press gallery for the 1992 session in order to provide broader camera angles and reaction shots. However, the local TV stations relied on the legislature's TV feeds for the vast majority of the footage used in their newscasts. Thus, the Supreme Court's decision that the Assembly may now exclude those cameras in the gallery will have only a limited impact on the television coverage that Nova Scotians enjoy.

At stake, however, was not simply whether TV cameras should be given access to legislative debates and committee hearings. The fundamental issue dealt with the reach of the Charter of Rights into the internal workings of the legislatures. Both the majority opinion written by McLachlin J. and the concurring opinion written by Lamer C.J. assert that the courts simply should not be allowed to apply the Charter to the privileges of our legislative bodies.

It is evident that the majority firmly believe that parliamentary privilege is an essential part of the general constitution of Canada that requires protection from the Charter. McLachlin J, and Lamer C.J. clearly depict the necessity of parliamentary privilege to the functioning of our form of democracy. The essence of the privilege lies in ensuring that the internal workings of a legislative assembly are not subject to scrutiny or interference from the courts; in many ways it is the corollary of judicial independence. All the courts may do is determine whether a matter is one of privilege. The test that has been developed by courts in Britain and Canada is that the privilege must be necessary to the functioning of the legislative body. If the assembly's control over the issue is necessary, then the courts have no jurisdiction to comment on the particular manner in which the legislature chooses to exert that control. Thus, McLachlin J. concludes that the nature and importance of parliamentary privilege is such that even subjecting a particular exercise of privilege to Charter scrutiny effectively destroys that privilege. These privileges are put out of reach of the Charter by declaring that they form part of the formal Constitution of Canada.

The majority's opinions present challenges for future resolution, since the desired outcome appears to have driven the justifications given. The convoluted reasoning used to explain this outcome will come back to haunt the Court in a number of future cases.

\section{THE CHARTER AND THE HOUSE OF ASSEMBLY}

The first issue that had to be resolved is whether the Charter of Rights applies to the House of Assembly. Chief Justice Lamer's concurring opinion takes the most remarkable position in deciding that s. 32(1) of the Charter defines the application of the Charter to include only the legislature as a whole, and not its constituent parts; in a basic reminder he points out that a legislature is composed of both the Assembly and the Lieutenant Governor. Lamer C.J.'s position is actually an expansion of the position argued by McIntyre J. in Dolphin Delivery, when he examined the meaning of s. 32(1): "[L]egislation is the only way in which a legislature may infringe a guaranteed right or freedom." 2 While this view was originally given in obiter, its importance was underlined when it was quoted with approval again by LaForest $\mathrm{J}$. in McKinney. ${ }^{3}$

In a blunt exhibition of distinguishing, McLachlin J.'s majority decision simply brushes these two precedents aside by saying that in neither instance did the judges consider the issues involved in the present case. McLachlin J. concludes that the constituent parts of the legislature are indeed subject to the Charter. There are two threads to her inclusion of the legislative chambers within the Charter's purview. She argues in the first instance that certain sections only make sense if they apply to the chambers, such as the language rights in ss. 17 and 18 . McLachlin J. also explores an alternative line that may have 
significant future implications. Without conclusively settling the issue, she argues that legislative assemblies may well fall under the rubric of "government" referred to in s. 32(1). This approach is explicitly developed by Cory $\mathrm{J}$. in his dissenting opinion. He concludes that the effect of s. 32(1) was to extend the Charter to "public actors;" since the legislative assemblies are public actors, they must be covered by the Charter.

Curiously, none of the judges who wrote opinions in Donahoe dealt with the implications of a decision made at the initiation of this suit in Nova Scotia's Supreme Court Trial Division. Nathanson J. ruled that the original action had to be amended to involve all 52 MLAs, since the House of Assembly is not a legal entity that can be sued. If the House of Assembly cannot be the subject of a legal suit, there is a very strong argument that the Charter simply cannot apply to it. Charter claims against political parties have been dismissed for this very reason. $^{4}$ Because of Nathanson J.'s finding, this case proceeded against the individual members of the House. None of the judges considered whether the Charter can be enforced against the individual members of a legislative body.

\section{THE CHARTER AND PARLIAMENTARY PRIVILEGE}

With McLachlin J.'s finding that the Charter does apply to the component chambers of a legislature, the only means left by which to achieve the objective of protecting parliamentary privilege from judicial review was the principle laid down in the Education Act Reference: ${ }^{5}$ the Charter cannot invalidate another part of the Constitution. Thus for McLachlin J. to safeguard parliamentary privilege she had to find that it forms part of the formal Constitution. It is this quest that leaves an unsettling legacy.

In Donahoe, the Supreme Court enters into the murky area that distinguishes the "constitution" of Canada from the "Constitution." The "constitution" involves all the formal legal documents (such as legislation, royal proclamations, letters patent and orders-in-council) as well as the informal constitutional conventions and traditions that together define the manner in which our system of government operates. The "Constitution," however, is a much smaller subset of the formal rules. Section 52 of the Constitution Act, 1982 defines the Constitution of Canada to "include" a specific group of documents listed in an appendix that collectively comprise the "supreme law." Because these rules are equally supreme law, one rule cannot be invalidated by another; hence, the Charter does not nullify anything in the Constitution. There is no doubt that parliamentary privilege is part of the larger constitution of Canada, but McLachlin J. goes further and asserts that it belongs to the formal Constitution.

McLachlin J. decides that the privileges of provincial legislatures enjoy constitutional status because of the declaration in the preamble of the Constitution Act, 1867 that the uniting provinces would be joined in a country "with a constitution similar in principle to that of the United Kingdom." She reasons that these privileges are inherently necessary for the legislatures to function and are thus an essential element of the Constitution that defines the parliamentary democracy inherited from Britain. Her decision is somewhat unclear as to whether parliamentary privilege is part of the Constitution simply because it flows from the words in one of the Constitution Acts, or whether some extra justification is needed. She launches into a discussion of the exhaustiveness of the definition of the Constitution of Canada in s. 52 of the 1982 Act. Her conclusion is that the list of documents is not exhaustive and that other rules may well be included in the formal Constitution. Her conclusion is an elegant display of curial articulation: ${ }^{6}$

I would be unwilling to restrict the interpretation of that section [s. 52] in such a way as to preclude giving effect to the intention behind the preamble to the Constitution Act, 1867 , thereby denying recognition to the minimal, but long recognized and essential, inherent privileges of Canadian legislative bodies.

McLachlin J. essentially argues that the preamble of the 1867 Act clearly intends that Canada enjoy the parliamentary democracy developed in Britain and that subsequent constitutional amendments accommodate certain prerequisites. She reflects: ${ }^{7}$

... I do not understand the entrenchment of written rights guarantees, or the adoption of specific written instruments, to negate the manifest intention expressed in the preamble of our Constitution that Canada retain the fundamental constitutional tenets upon which British parliamentary democracy rested.

This use of the 1867 Act's preamble to entrench an unwritten principle may seem quite startling, but the Supreme Court has done this before. In the Senate Reference, ${ }^{8}$ the Court unanimously held that the preamble's reference to "a constitution similar in principle to that of the United Kingdom" meant that Canada's Senate was intended to be an appointed chamber like the House of Lords. As a result, legislation to abolish the senate or to provide for indirect senate elections would be unconstitutional.

What is unusual in Donahoe is the implication that a whole range of constitutional rules may now be considered part of the formal Constitution, because they are considered essential to parliamentary democracy. McLachlin J. clearly envisions parliamentary privilege as just one aspect of our British constitutional framework referred to in the preamble of the Constitution Act, 1867.

However, McLachlin J. also places some limitations upon what might be imported through the preamble: ${ }^{9}$ 
This is not a case of importing an unexpressed concept into our constitutional regime, but of recognizing a legal power fundamental to the constitutional regime which Canada adopted in its Constitutional Acts, 1867 to 1982 . Nor are we here treating a mere convention to which the courts have not given legal effect; the authorities indicate that the legal status of inherent privileges has never been in doubt.

She is clearly trying to restrict her argument to rules whose legal nature is already firmly recognized.

\section{PROBLEMS WITH ENTRENCHED PRIVILEGE}

The constitutional status that the Court has accorded parliamentary privilege poses some tangible difficulties, as Sopinka J. points out in his concurring opinion. If a provincial legislature's privileges truly are part of the Constitution of Canada, their amendment is out of reach of simple legislation by that legislature. Under the amending formula of the Constitution Act, 1982, the provincial legislatures may change the "constitution of the province" by ordinary legislation. But this flexible amending power does not extend to provisions relating to the province that are contained in the Constitution of Canada. Such an amendment requires the agreement of at least the national parliament under s.43; some provincial matters in the Constitution even require unanimous consent. As Sopinka J. dryly comments: "It seems to me that the prospect of losing legislative control over its rights and privileges would be a high price for the appellant to pay in order to escape the Charter."

McLachlin J.'s majority decision blithely ignores these tremendous consequences of her reasoning. In its determination to save legislative privileges from judicial scrutiny under the Charter, the Supreme Court majority may have entrenched many aspects of provincial constitutions beyond the reach of their legislatures.

The Donahoe decision leaves a number of related issues unresolved. If a legislature's privileges are not subject to the Charter, problems arise in deciding what force remains in those provisions of the Charter that do explicitly relate to the legislatures. For instance, the regulation of what language is spoken in a chamber is essential to a chamber's efficient functioning and, through the necessity test, could be considered a matter of privilege; if members spoke in languages that none of their colleagues understood there would be little business conducted in the House. And yet, ss. 17 and 18 of the Charter declare that either French or English may be used in Parliament and the New Brunswick legislature. Under the logic of the majority decision, parliamentary privilege must be entirely exempt from judicial scrutiny under the Charter; the language rights would be unenforceable since they appear to be largely coextensive with a parliamentary privilege.
However, McLachlin J. does leave the Court some elbow room in her decision. She makes an undeveloped comment that: ${ }^{11}$

Absent specific Charter language to the contrary the long history of curial deference to the independence of the legislative body, and to the rights necessary to the functioning of that body, cannot be lightly set aside... (Emphasis added).

An enterprising judge may find some way to distinguish Donahoe and argue that judicial review of parliamentary privilege should be permitted if a right enumerated in the Charter, such as one of the language provisions, can only be exercised in a context considered to be a matter of privilege.

A situation developed during the 1993 Nova Scotian elections that might see the Donahoe decision applied in a different setting. Conservative Premier Don Cameron refused to sign the papers for Paddy Fitzgerald, who had won his riding's nomination, because of a 1979 conviction for rape. Fitzgerald then threatened legal action against his party leader. ${ }^{12}$

Several aspects of Donahoe could be brought to bear in a case like Fitzgerald's. Previous attempts to launch Charter claims against political parties have been dismissed on the grounds that parties do not have the legal status to be sued. But legislative chambers cannot be sued either, and this was not even considered as an impediment in Donahoe. The broad sweep given to the Charter's application to "government" could conceivably be extended to include political parties. Political parties are so intricately enmeshed in both the legislative and executive branches of government that it is difficult not to describe them as "public actors;" party groupings structure and determine the main decisions made by the executive and legislature. Thus, a party leader's refusal to endorse a candidate's nomination could be argued to be an infringement of a person's Charter right to be a candidate.

Since McLachlin J.'s comments about the broad application of the Charter to "government" were made in obiter, there is some chance that another judge in a future case would give these comments the same short shrift given McIntyre J.'s statement about the Charter only applying to the legislative output of a legislature. A chaotic pandora's box would be opened if Donahoe were used to apply the Charter to political parties. 


\section{CURIOSITIES OF LOGIC}

Some anomalies emerge in the positions taken in the various opinions offered in Donahoe. McLachlin J.'s decision seems to assume that legislative privileges are a fairly settled and defined set of principles; which is not entirely the case. Since McLachlin J. appears to exempt all parliamentary privilege from the Charter, it seems that even statutes that embody or extend rules of privilege are not subject to the Charter. It is unclear how the majority of the Court would react to fresh assertions of completely new privileges that arise because of unforeseen developments. The courts may come to assess claims to new privileges in the light of the Charter, in order to determine whether these privileges are truly necessary and defensible under contemporary legal norms.

Some strange consequences flow from Lamer C.J.'s position that the Charter applies to legislation but not to the legislative chambers. While Lamer C.J. would permit any assertion of privileges by legislative chambers to go unexamined by the courts, his rationale would subject any legislation relating to privilege to Charter scrutiny.

Lamer C.J. is the only member of the Court to avoid a glaring oversight, but in doing so leaves his opinion with a troublesome inconsistency. His colleagues manage to discuss the privileges of the Nova Scotia legislative assembly without once mentioning s. 36 of the House of Assembly $\dot{A} t^{13}$ which provides the legal basis for the privileges that are at issue in this case:

36(1) In all matters and cases not specially provided for by an enactment of this Province, the House and committees and members thereof respectively shall hold, enjoy and exercise such and like privileges, immunities and powers as are from time to time held, enjoyed and exercised by the House of Commons of Canada, and by the committees and members thereof respectively.

Even though Lamer C.J. does include this section in his list of legal provisions relating to the case, he never refers to it again. This is odd in the extreme since he concludes: "The legislation that the provinces have enacted with respect to privileges will be reviewable under the Charter as is all other legislation."14 In their efforts to achieve their objective of isolating legislative privilege from the Charter, the judges have plainly ignored the existence of ordinary legislation that provides the basis for the actions of the House of Assembly which are at issue.

One consequence of McLachlin J.'s decision, which builds on the Education Act Reference, is that Parliament could circumvent any future scrutiny of a range of matters simply by legislating them into the Constitution of Canada. Section 44 of the Constitution Act, 1982 permits Parliament to amend the Constitution by simple legislation if it relates to a range of matters dealing with "the executive government of Canada or the
Senate and the House of Commons." ${ }^{15}$ And, a province may entrench many matters in its jurisdiction out of reach of the Charter if the national Parliament agrees.

\section{CONCLUSION}

With its decision in Donahoe, the Supreme Court of Canada has broken some novel constitutional ground. The range of privileges claimed by Canadian legislatures has largely been protected from judicial scrutiny. While Dolphin Delivery prevented the Charter from applying to many actions of the courts, Donahoe has placed limits on the Charter's application to the legislatures. Students of the Constitution should note that the Charter of Rights does not govern all actions by state institutions and officials.

The consequences of Donahoe, however, reach far beyond this limitation on the Charter. The Court has entrenched a range of constitutional principles in the Constitution, because they are necessary to the "Constitution similar in principle to that of the United Kingdom" referred to in the preamble to the Constitution Act, 1867. Just how far this range of entrenched principles extends and how amendments to them may be affected will be left for the Supreme Court to decide in future cases.

Andrew Heard, Department of Political Science, Simon Fraser University.

1. [1993] I S.C.R. 319.

2. RWDSU v Dolphin Delivery Ltd., [1986] 2 S.C.R. 573 at 599.

3. MCKinney v. University of Guelph, [1990] 3 S.C.R. 229 at 263.

4. McKinney v. Liberal Party of Canada et al. (1987), 61 O.R. (2d) 680 (Ont. H.C.J.); McKinney v. Mazankowski et al. (23 November 1988), (Ont.H.C.J.) [unreported].

5. Reference re Bill 30, An Act to amend the Education Act (Ont.), [1987] 1 S.C.R. 1148

6. Supra note 1 at 378

7. Ibid. at 377

8. Reference re Legislative Authority of Parliament to Alter or Replace the Senate, [1980] 1 SCR 54.

9. Supra note 1 at $377-378$.

10. Ibid. at 396.

11. Ibid. at 372 .

12. Vancouver Sun (30 April 1993) A9

13. R.S.N.S. 1989, c.210.

14. Supra note 1 at 364 .

15. This amending power is regulated by ss. 41 and 42 , which stipulate that certain matters can only be achieved with the participation of the provinces. 